\title{
Wage-Increment and Development of Black Economy in Nigeria: Influences of Inflation and Taxation
}

\section{Emmanuel O. Okon ${ }^{1}$}

${ }^{1}$ Ph.D, Deptartment of Economics, Kogi State University, Kogi State, Nigeria

\author{
Article Info \\ Article history: \\ Received: 09 September 2020 \\ Revised: 07 November 2020 \\ Accepted: 07 November2020 \\ Keywords: \\ Wage-Increment, \\ Black Economy, \\ Stationarity, \\ Impulse Response Function, \\ Inflation. \\ JEL: C51, E60, H70, J46, \\ O17 \\ Paper Type : \\ Research Article \\ Corresponding Author: \\ Emmanuel O. Okon \\ Email: \\ Emmanuel.oo@ksu.edu.ng
}

\begin{abstract}
Purpose: In this paper, wage-black economy relationship was examined while taking into consideration the influences of inflation and taxation.

Approach/Methodology/Design: In particular, Value at Risk (VAR) approach was implemented using annually data for Nigeria covering the period 1990 2018 to assess the dynamic relationship among the variables. In light of national minimum wage in Nigeria, impulse response function was used to highlight the plausible responses from black economy to a shock of one standard deviation in each indicated variable.

Findings: The result shows that a shock to national minimum wage (LOGMWA) will have a negative effect on black economy (LOGBEC) in Nigeria. Shocks to inflation (LOGINFL) will have a positive impact on black economy (LOGBEC). Shocks to tax (LOGATAX) will have asymmetric impacts on black economy (LOGBEC). The results were robust even when unemployment (LOGUEMP) was included. An unemployment shock was shown to enhance black economy in Nigeria.

Practical Implications: The study is significant for the concerned authorities in Nigeria so that policy measures are taken and directed towards the causes that drive the black economy in the country.

Originality/value: The impulse response function was estimated. It was estimated to show the plots of the responses from black economy (LOGBEC) to a one standard deviation shock in each indicated variable (national minimum wage (LOGMWA), inflation (LOGINFL), and tax (ATAX)). The shocks to national minimum wage (LOGMWA) will have a negative effect on black economy (LOGBEC) in Nigeria.
\end{abstract}

\section{Introduction}

Many governments around the world set a minimum wage in order to raise wages of workers whose wages are relatively low. Minimum-wage laws dictate the lowest price for labour that any employer may pay (Mankiw, 2011). Hence, requiring that firms or organizations pay minimum wages are illustrations of government interventions designed to raise the income of specific groups; the purpose of which is to provide a 'wage floor' that will help less-skilled workers earn enough income to escape poverty (McConnell et al., 2009). Minimum wage policy supported by a strong social policy is an efficient mechanism against poverty and income erosion of the poorest households. Herr and Kazandziska (2011) assert that minimum wage is one of the instruments which can control wage dispersion and in this way reduce income inequality. It can also help to prevent a general decline in the level of nominal wages and deflationary developments. Over time, the Nigerian workers have been asking for a general upward review of wages and an increase in the National Minimum Wage. One of the reasons is that the inflation has intensified with the cost of living index in the urban sector increasing. 
The disproportionate increase in the cost of food means that the erosion in the real wages and salaries of workers is alarmingly severe. The process of monetizing and consolidating in-kind benefits which were hitherto not taxed resulted in escalation of the tax paid by workers. This further depressed the real take home pay of workers (Jonah, 2009). The likelihood of workers resorting to unreported economic activities in order to make ends meet becomes high.

Association of Chartered Certified Accountants (ACCA) in a recent study revealed that the black economy in Nigeria represented 48.37 per cent of GDP in 2016 - which is approximately N 49.67 trillion (Okechukwu, 2017). There have been other studies on the issue of black economy in Nigeria (Elijah and Uffort 2007; Ihendinihu and Ochonma 2010; Ariyo and Bekoe 2012; Ogbuabor and Malaolu 2013; Ihendinihu 2013; and Nmesirionye and Ihendinihu, 2016), however, the literature still remains scanty. As such, this paper is a contribution to filling the gap in research.

\section{Methodology and Procedures}

This paper adopts quantitative methodological framework in order to capture the relationship among the variables of interest. The data for this study were obtained mainly from secondary sources; particularly from GlobalEconomy.com portal, Index Mundi portal, Knoema.com, CBN Statistical Bulletin and relevant literatures. The data used covered 1990 -2018. The rationale behind selecting these periods is the availability of data. The dependent variable was black economy as percent of total annual GDP (BEC), while the National Minimum Wage (MWA), tax (proxy by average tax revenue (ATAX)), and inflation rate (INFL) served as the explanatory variables in the formulation of the model which captures the relationship among the variables of interest. All the variables employed were first transformed into logarithms to account for nonlinear properties and heteroscedasticity. The technique of analysis was Vector Autoregression (VAR) model which is an extension of univariate autoregression model to multivariate time series data.

\section{Results and Discussion}

Table 1: ADF Unit Root Test Result

\begin{tabular}{llll}
\hline Variables & ADF statistics & Critical Value & Order of Integration \\
\hline ATAX & -4.611292 & $-4.339330^{*}$ & $I(1)$ \\
INFL & -4.203480 & $-3.587527^{* *}$ & $I(1)$ \\
MWA & -5.393242 & $-4.339330^{*}$ & $I(1)$ \\
BEC & -7.387237 & $-4.339330^{*}$ & $I(1)$ \\
UEMP & -5.065387 & $-4.339330^{*}$ & $I(1)$ \\
\hline
\end{tabular}

Source: Author's computation using eviews software 9

Note: * Indicates stationary at the $1 \%$ level, and ** Indicates stationary at $5 \%$ level.

From the table above, the unit root test results of the incorporated times series variables in the regression model are presented. Using Schwarz Info Criterion, maximum lag length of 6 and trend and intercept, the traditional test of the ADF here indicates that almost all the variables tend to be stationary in first difference. Under this scenario, there is need to test for cointegration. As such, Phillips and Ouliaris (1990) single-equation residual-based cointegration 
tests was applied. The cointegration test is a simply unit root tests applied to the residuals obtained from a static Ordinary Least Squares cointegrating regression. Under the assumption that the series are not cointegrated, the residuals are unit root nonstationary. Therefore, a test of the null hypothesis of no cointegration against the alternative of cointegration may be constructed by computing a unit root test of the null of residual nonstationarity against the alternative of residual stationarity.

Table 2 shows the Phillips-Ouliaris test statistics using default settings in EViews software to compute the long-run variances by applying Bartlett kernel estimator with a fixed Newey-West bandwidth.

Table 2: Phillips-Ouliaris test statistic

\begin{tabular}{ccccc} 
Dependent & tau-statistic & Prob.* & z-statistic & Prob.* \\
\hline & & & & \\
LOGMWA & -3.914973 & 0.1384 & -15.51732 & 0.3410 \\
LOGINFL & -3.601749 & 0.2205 & -17.37936 & 0.2381 \\
LOGATAX & -3.179621 & 0.3768 & -14.95233 & 0.3764 \\
LOGBEC & -4.479985 & 0.0530 & -22.40844 & 0.0691
\end{tabular}

*MacKinnon (1996) p-values.

Source: Author's computation using eviews software 9

Regarding the test results, both the Phillips-Ouliaris tau-statistic ( $t$-statistic) and normalized autocorrelation coefficient (which is termed the $z$-statistic) for residuals were obtained using each series in the group as the dependent variable in a cointegrating regression. It can be seen that the results for the tau-statistic are mixed. Most of the residuals uniformly failed to reject the null hypothesis of no cointegration at conventional levels except for residuals from LOGBEC equation rejecting the unit root null at the $10 \%$ level. The results for the $z$-statistics are also mixed, with the residuals from the LOGBEC equation rejecting the unit root null at the $10 \%$ level. On balance, however, the test statistics suggest that the null hypothesis of no cointegration cannot be rejected. This indicates that there is no long-run relationship among the series. The implication is that, if there are shocks to the system, the model is not likely to converge in the long-run. In addition, if there is no cointegration, only the short-run model should be estimated. That is, only vector autoregressive (VAR) estimation technique should be applied and not a vector error correction (VECM) technique. The structure of the vector autoregression (VAR) model is that each variable is a linear function of past lags of itself and past lags of the other variables. The VAR was specified in levels because according to Cuthberson (2002) VAR in differences would be mis-specified.

In ordering the variables, it was assumed that inflation and tax affect minimum wage such that minimum wage influence the growth of black economy. For the selection of lag length, a lag length of one is selected based on Schwarz information criteria because it takes into consideration the parsimoniousness of the model and degree of freedom. Table 3 shows the unrestricted VAR 4-variable model result. 
Table 3: Vector Autoregression Estimates

\begin{tabular}{|c|c|c|c|c|}
\hline & LOGBEC & LOGMWA & LOGINFL & LOGATAX \\
\hline LOGBEC(-1) & $\begin{array}{c}0.287409 \\
(0.18302) \\
{[1.57038]}\end{array}$ & $\begin{array}{c}0.607924 \\
(1.46186) \\
{[0.41586]}\end{array}$ & $\begin{array}{c}0.187697 \\
(1.64117) \\
{[0.11437]}\end{array}$ & $\begin{array}{c}3.420332 \\
(1.89137) \\
{[1.80839]}\end{array}$ \\
\hline LOGMWA(-1) & $\begin{array}{c}-0.025898 \\
(0.01146) \\
{[-2.25976]}\end{array}$ & $\begin{array}{c}0.833454 \\
(0.09154) \\
{[9.10476]}\end{array}$ & $\begin{array}{c}-0.023215 \\
(0.10277) \\
{[-0.22590]}\end{array}$ & $\begin{array}{c}0.209241 \\
(0.11844) \\
{[1.76669]}\end{array}$ \\
\hline LOGINFL(-1) & $\begin{array}{c}0.021087 \\
(0.01831) \\
{[1.15154]}\end{array}$ & $\begin{array}{c}-0.378564 \\
(0.14626) \\
{[-2.58825]}\end{array}$ & $\begin{array}{c}0.580814 \\
(0.16420) \\
{[3.53716]}\end{array}$ & $\begin{array}{c}-0.085169 \\
(0.18924) \\
{[-0.45007]}\end{array}$ \\
\hline LOGATAX(-1) & $\begin{array}{c}0.024072 \\
(0.01545) \\
{[1.55832]}\end{array}$ & $\begin{array}{c}0.003204 \\
(0.12339) \\
{[0.02597]}\end{array}$ & $\begin{array}{c}-0.180524 \\
(0.13852) \\
{[-1.30322]}\end{array}$ & $\begin{array}{c}0.585628 \\
(0.15964) \\
{[3.66846]}\end{array}$ \\
\hline $\mathrm{C}$ & $\begin{array}{c}3.035151 \\
(0.78408) \\
{[3.87098]}\end{array}$ & $\begin{array}{c}0.087493 \\
(6.26279) \\
{[0.01397]}\end{array}$ & $\begin{array}{c}0.545452 \\
(7.03100) \\
{[0.07758]}\end{array}$ & $\begin{array}{c}-15.19837 \\
(8.10290) \\
{[-1.87567]}\end{array}$ \\
\hline R-squared & 0.584212 & 0.937204 & 0.570535 & 0.740866 \\
\hline Adj. R-squared & 0.511901 & 0.926283 & 0.495846 & 0.695800 \\
\hline Sum sq. resids & 0.065552 & 4.182199 & 5.271135 & 7.000844 \\
\hline S.E. equation & 0.053386 & 0.426421 & 0.478727 & 0.551711 \\
\hline F-statistic & 8.079172 & 85.81687 & 7.638766 & 16.43932 \\
\hline Log likelihood & 45.06925 & -13.11114 & -16.35085 & -20.32385 \\
\hline Akaike AIC & -2.862089 & 1.293653 & 1.525061 & 1.808846 \\
\hline Schwarz SC & -2.624195 & 1.531546 & 1.762955 & 2.046740 \\
\hline Mean dependent & 4.037440 & 8.334651 & 2.670754 & 0.031501 \\
\hline S.D. dependent & 0.076415 & 1.570564 & 0.674228 & 1.000303 \\
\hline \multicolumn{2}{|c|}{ Determinant resid covariance (dof adj.) } & $2.67 \mathrm{E}-05$ & & \\
\hline \multicolumn{2}{|c|}{ Determinant resid covariance } & $1.22 \mathrm{E}-05$ & & \\
\hline \multicolumn{2}{|c|}{ Log likelihood } & -0.496326 & & \\
\hline \multicolumn{2}{|c|}{ Akaike information criterion } & 1.464023 & & \\
\hline \multicolumn{2}{|c|}{ Schwarz criterion } & 2.415598 & & \\
\hline
\end{tabular}

Source: Author's computation using Eviews 9 software

The results of the VAR analysis in table 3 at lag one indicates that the variables are dynamically interacted. Starting with the equation of black economy (equation 1) which is the main focus, a $1 \%$ increase in the previous values of black economy (LOGBEC), national minimum wage (LOGMWA), inflation (LOGINFL), and tax (LOGATAX) lead to a $0.287409 \%$ increase, $0.025898 \%$ decrease, $0.021087 \%$ increase, $0.024072 \%$ increase in current black economy respectively. Followed by the equation of national minimum wage (LOGMWA), a $1 \%$ increase in the previous values of black economy (LOGBEC), national minimum wage (MWA), inflation 
(LOGINFL), and tax (LOGATAX) lead to a $0.607924 \%$ increase, $0.833454 \%$ increase, $0.378564 \%$ decrease, and $0.003204 \%$ increase in current national minimum wage (LOGMWA) respectively.

On the equation of inflation (LOGINFL), a 1\% increase in the previous values of black economy (LOGBEC), national minimum wage (LOGMWA), inflation (LOGINFL), and tax (ATAX) lead to a $0.187697 \%$ increase, $0.209241 \%$ increase, $0.580814 \%$ increase, $0.180524 \%$ decrease in current inflation (LOGINFL) respectively. The equation of tax (LOGATAX) shows that a $1 \%$ increase in the previous values of black economy (LOGBEC), national minimum wage (LOGMWA), inflation (LOGINFL), and tax (ATAX) lead to a $3.420332 \%$ increase, $0.209241 \%$ increase, $0.085169 \%$ decrease, and $0.585628 \%$ increase in current tax (ATAX) respectively. The overall goodness of fit shows that $58.4 \%$ variation in inflation is caused by the variations in the previous values of black economy (LOGBEC), national minimum wage (LOGMWA), inflation (LOGINFL), and tax (ATAX).While 93.7\% variation in national minimum wage (LOGMWA) is caused by the joint variation in the previous values of black economy (LOGBEC), national minimum wage (LOGMWA), inflation (LOGINFL), and tax (ATAX).

The equation of inflation (LOGINFL) indicates that $57.1 \%$ variation in inflation is caused by the joint variation in the previous values of black economy (LOGBEC), national minimum wage (LOGMWA), inflation (LOGINFL), and tax (ATAX). While $74.1 \%$ variation in tax (ATAX) is caused by the joint variation in the previous values of black economy (LOGBEC), national minimum wage (LOGMWA), inflation (LOGINFL), and tax (ATAX). No doubt, individual coefficients in the estimated VAR models have been interpreted but since all variables in a VAR model depend on each other, individual parameter values only provide limited information on the reaction of the system to a shock. In order to get a better intuition of the model's dynamic behaviour, impulse responses are used (this happens to be the focus of analysis in this paper). The IRF traces out the response of the dependent variable in the VAR system to shocks in the error terms. Put simply, an impulse response function traces the effect of a one-time shock to one of the innovations on current and future values of the endogenous variables. Invariably, a shock to the $i$-th variable not only directly affects the $i$-th variable but is also transmitted to all of the other endogenous variables through the dynamic (lag) structure of the VAR.

Nonetheless, some diagnostics were tested for before proceeding with the impulse response analysis. First, the autocorrelation LM test using 2 lag shows that the error are not serially correlated. The VAR residual Heteroskedasticity tests with no cross terms indicates that errors are homoskedastic. Based on these, the impulse response function was estimated. It was estimated to show the plots of the responses from black economy (LOGBEC) to a one standard deviation shock in each indicated variable (national minimum wage (LOGMWA), inflation (LOGINFL), and tax (ATAX)). It was done for two purposes; first, to examine whether higher national minimum wage reduces black economy; second, to investigate the effect of increase in inflation and taxation on the size of black economy in Nigeria. Nonetheless, high tax is known to depress the real take home pay of workers while increase in inflation erodes workers' wages and salaries, thus, leading to demand for higher minimum wage. 
Table 4: VAR Residual Serial Correlation LM Tests

\begin{tabular}{ccc}
\hline Lags & LM-Stat & Prob \\
\hline 1 & 13.39698 & 0.6435 \\
2 & 6.179781 & 0.9860
\end{tabular}

Probs from chi-square with $16 \mathrm{df}$.

Source: Author's computation using Eviews 9 software

Table 5: VAR Residual Heteroskedasticity Tests: No Cross Terms (only levels and squares)

Joint test:

\begin{tabular}{ccc}
\hline Chi-sq & Df & Prob. \\
\hline 95.64805 & 80 & 0.1119
\end{tabular}

Individual components:

\begin{tabular}{lccccc}
\hline Dependent & R-squared & $\mathrm{F}(8,19)$ & Prob. & Chi-sq(8) & Prob. \\
\hline res1*res1 & 0.262835 & 0.846803 & 0.5747 & 7.359381 & 0.4984 \\
res2*res2 & 0.315882 & 1.096625 & 0.4073 & 8.844705 & 0.3556 \\
res3*res3 & 0.268206 & 0.870449 & 0.5573 & 7.509766 & 0.4828 \\
res4*res4 & 0.807176 & 9.941936 & 0.0000 & 22.60093 & 0.0039 \\
res2*res1 & 0.196778 & 0.581841 & 0.7804 & 5.509778 & 0.7020 \\
res3*res1 & 0.343451 & 1.242401 & 0.3286 & 9.616638 & 0.2930 \\
res3*res2 & 0.159949 & 0.452209 & 0.8741 & 4.478569 & 0.8116 \\
res4*res1 & 0.241485 & 0.756118 & 0.6439 & 6.761582 & 0.5626 \\
res4*res2 & 0.246494 & 0.776930 & 0.6277 & 6.901819 & 0.5473 \\
res4*res3 & 0.443416 & 1.892098 & 0.1212 & 12.41564 & 0.1336
\end{tabular}

Source: Author's computation using Eviews 9 software 
Response to Cholesky One S.D. Innovations \pm 2 S.E.

Response of LOGBEC to LOGMWA

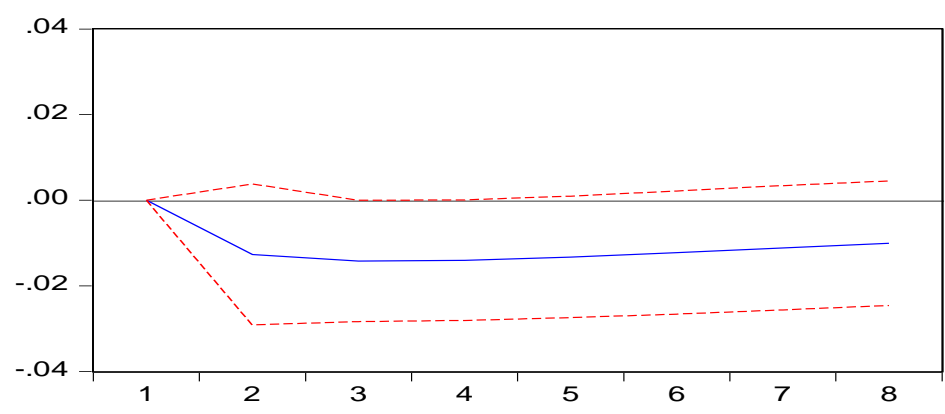

Response of LOGBEC to LOGINFL

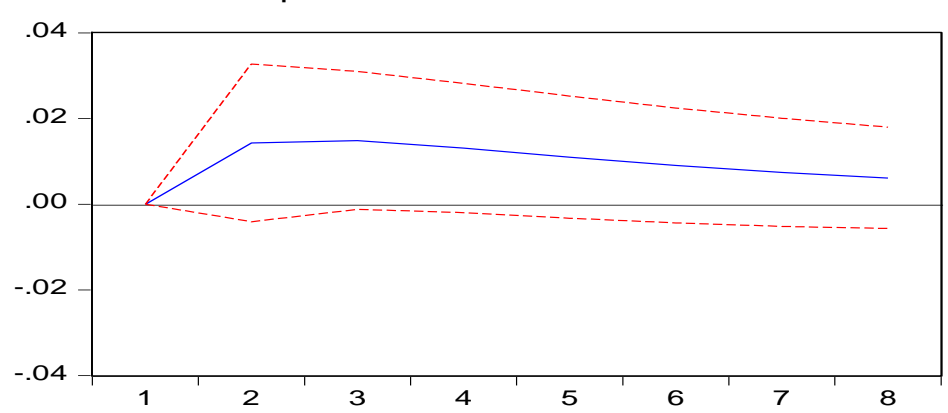

Response of LOGBEC to LOGATAX

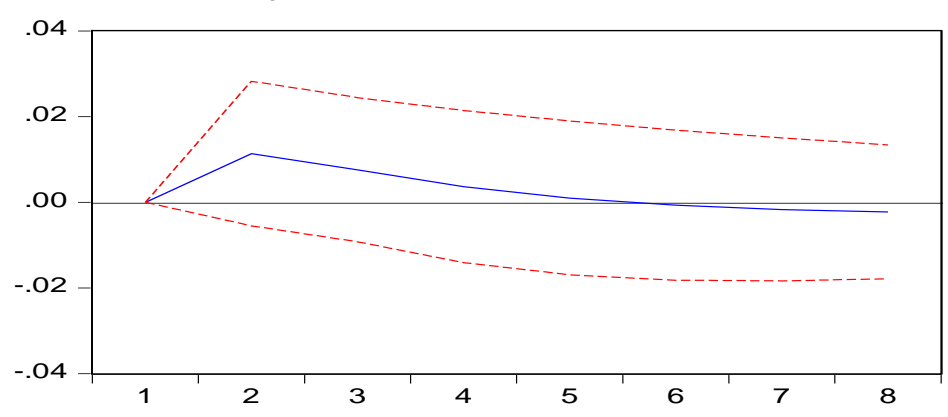

Figure 1: Response to Choleskey One S.D. Innovation $s+2$. S.E Source: Author's computation using Eviews 9 software

In Figure 1, the blue or middle line shows the impulse function while the red or dotted lines show the $95 \%$ confidence intervals. It depicts that in response to a one standard-deviation increase in national minimum wage (LOGMWA), black economy (LOGBEC) falls and stays below its steady-state value all through the periods. The fall was sharp from $1^{\text {st }}$ period to $2^{\text {nd }}$ period. A further fall was experienced in period 3. Thereafter, it fell but at a decreasing rate but still remaining in the negative region. In sum, the shocks to national minimum wage (LOGMWA) will have a negative effect on black economy (LOGBEC) in Nigeria. This result is contrary to a new study in Germany that shows that the introduction of a nationwide minimum wage is driving more workers into the shadows (DW, 2015). Nonetheless, this result aligns with Burnett (2018) that raising the minimum wage would stabilize families - and destabilize the black economy. 
On March 19, 2019, the new national minimum wage bill, an issue that featured widely in the 2019 presidential campaigns in Nigeria, finally received legislative approval. The Senate approved $\$ 30,000$ as the new National minimum wage, after nearly 8 years of no-increase from the 18,000 paid as minimum wage since 2011 (CSEAAfrica, 2019). The minimum wage in Nigeria is based on monthly income with an average working period of 8 hours daily and 5 days weekly (WageIndicator, 2019). The Nigeria Labour Congress and the Nigerian government came to an agreement over the implementation of the new minimum wage scheme. Both parties agreed on 23.2 percentage increase for workers on grade level 07; 20 percent for those at grade level 08; 19 percent for workers at grade level 09; 16 percent for those at grade levels 10 to 14; and 14 percent for workers at grade levels 15 to 17 (Saharareporters, 2019).

A closer look at Figure 1 reveals that a one standard deviation shock (innovation) to inflation (LOGINFL) initially increases LOGBEC in periods 1,2 and 3. From the $3^{\text {rd }}$ period, this positive response gradually declines to about the $8^{\text {th }}$ period but remains in the positive region. The bottom line is that shocks to inflation (LOGINFL) will have a positive impact on black economy (LOGBEC). According to CSEAAfrica (2019), theoretically, businesses are forced to raise prices when there is an increase in minimum wage, and this ultimately places cost-push inflationary pressures on the economy. Real business practices conform to this theory. A strategic attempt to absorb increasing labour costs tend to cause producers to transfer the cost of wage increase to product prices, which are eventually borne by consumers in form of higher prices. For example, in 2003 when the Nigerian government reviewed a wage increase, prices of goods and services rose, and inflation rate spiked from about $10.5 \%$ to as high as $24 \%$ (CSEAAfrica, 2019). A similar wage-increase in 2011 saw the inflation rate remain at doubledigit for two years thereafter, according to data from the CBN (CSEAAfrica, 2019). If implemented, the 2019 wage increase may cause inflation rate to extensively exceed the CBN's $12 \%$ projection and gradually erode purchasing power and value of the new minimum wage in the long term. By then, the cycle of agitations for another wage raise may come into effect, yet again.

A further examination of Figure 1 depicts that after a positive tax (LOGATAX) shock (i.e., high tax), black economy initially increases sharply between periods 1 and 2 . From the $2^{\text {nd }}$ period, this positive response gradually declines to the $3^{\text {th }}$ period and continuously decreased till it hits the steady state value half way before the $7^{\text {th }}$ period. Thereafter, it remains in the negative region till the $8^{\text {th }}$ period. The implication is that shocks to tax (LOGATAX) will have asymmetric impacts on black economy (LOGBEC) in Nigeria. This result adds to the existing estimates of the effect of taxes on the shadow economy which appears to be highly inconsistent across different studies and vary from being positive and significant in early one country studies (Clotfelter, 1983; Slemrod, 1985; Schneider 1986) to being insignificant or even strongly negative in the latest cross-country literature (Johnson et al, 1998; Friedman et al, 2000; Torgler and Schneider, 2006).

Currently, in Nigeria, value-added tax rate (VAT) is likely to go up to enable government fund the new minimum wage of N30,000 per month approved by the National Assembly (Oyedele, 
2019). The intention according to Federal Inland Revenue Service is to increase compliance rate and not tax rates but says Nigerians should be ready for a VAT rate increase by the end of 2019 (Oyedele, 2019). Potentially this means an increase of about $50 \%$ will raise the current standard VAT rate of $5 \%$ to $7.5 \%$. Beyond the revenue impact, there will be other unintended consequences including: higher inflation, interest rate hike, more unemployment and people will generally become poorer (Oyedele, 2019) and eventually tilt to the underground economy to cushion the effect.

The baseline results were extended by including unemployment (UNEMP). The rationale is based on empirical evidences (e.g., World Bank) suggesting that employment effects of a rise in the minimum wage are often significant and negative, particularly in a largely informal labor market like Nigeria. By reorganizing internal human resource structure, businesses that lack the capacity to keep up with an increase in overhead costs may take drastic measures such as retrenching workers and downsizing labor time. With a number of job losses and layoffs, unemployment and underemployment rates are forced to increase. This may foster some dependency on black economy activity. A survey by the NBS showed that between 2011 when there was a rise in minimum wage and 2012, about 1.43 million people who were fully employed or underemployed lost their jobs (CSEAAfrica, 2019).

Although there was an increase in the labor force population, the total number of unemployed persons rose by $82.5 \%$ to 7.3 million (CSEA Africa, 2019). It is likely that the implementation of the 2019 approved minimum wage may project a similar trend given past occurrences. As such, there is a need to examine the extent of participation in the shadow economy by the unemployed.

Figures 2 clearly presents the results of this exercise. The outcomes remained quite the same. In response to a one standard-deviation increase in unemployment (LOGUEMP), black economy (LOGBEC) initially increases in periods 1,2 and 3. From the $3^{\text {rd }}$ period, it stays flat till period 6 where it slightly declines to about the $8^{\text {th }}$ period but remains in the positive region. The bottom line is that shocks to unemployment (LOGUEMP) will have a positive effect on black economy (LOGBEC) in Nigeria. This result adds to the list of literature that showed that high levels of unemployment tend to have a higher share of the informal economy in total GDP (Boeri and Garibaldi, 2002; Dell'Anno and Solomon, 2008; Dobre et al., 2010; Alexandru et al., 2010; Davidescu et al., 2015; Mauleón and Sardà, 2017). 
Response to Cholesky One S.D. Innovations \pm 2 S.E.

Response of LOGBEC to LOGMWA

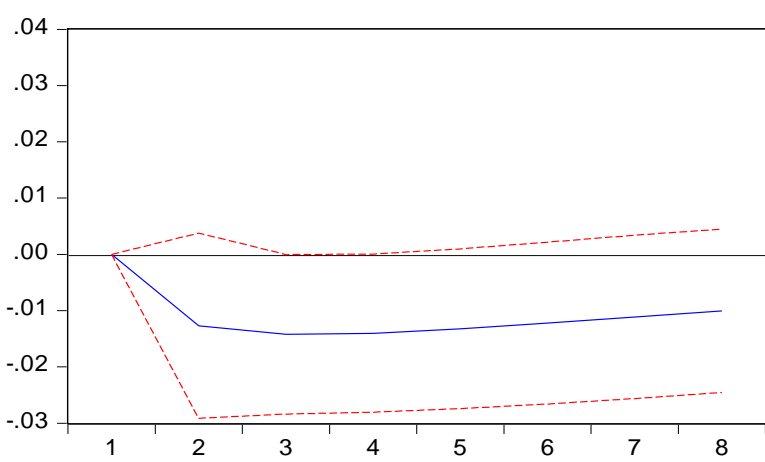

Response of LOGBEC to LOGATAX

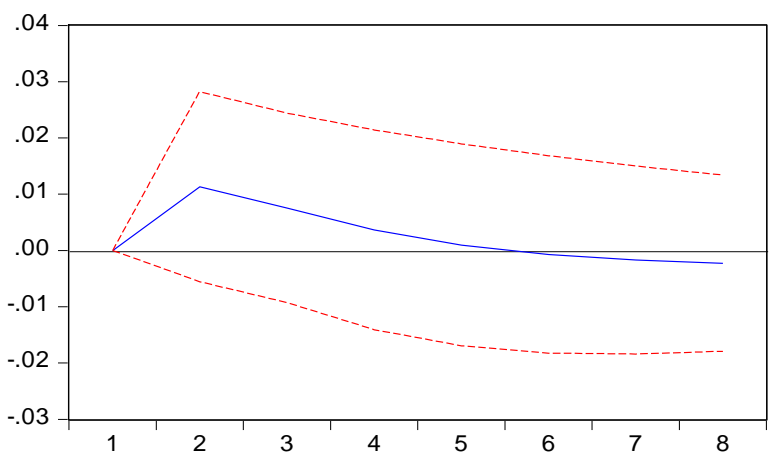

Response of LOGBEC to LOGINFL

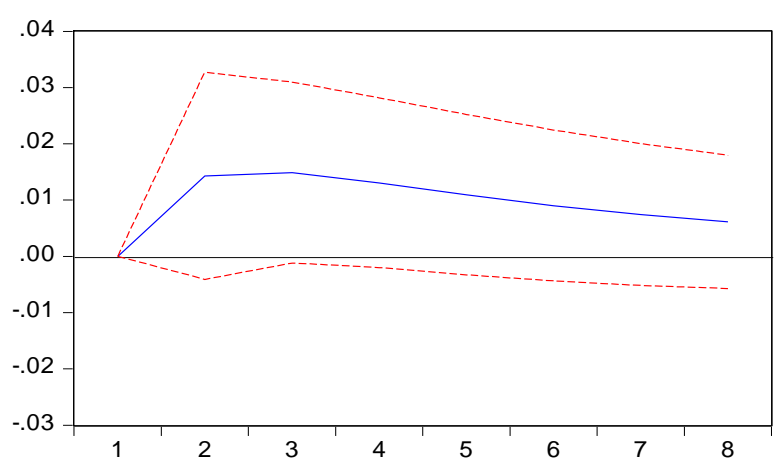

Response of LOGBEC to LOGUEMP

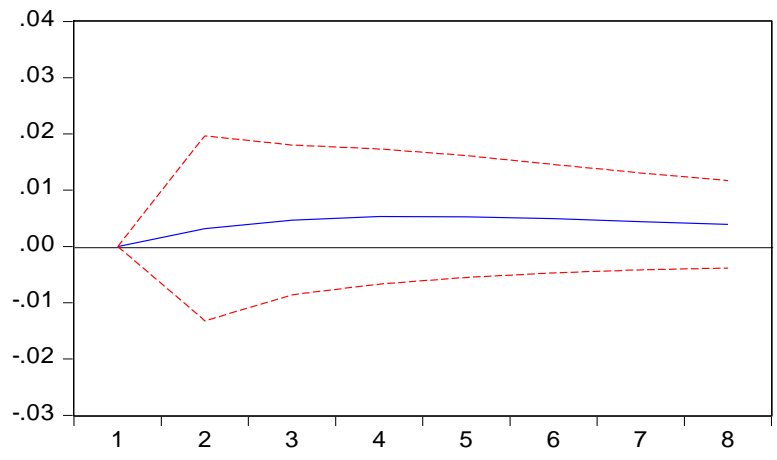

Figure 2: Response to Choleskey One S.D. Innovation $s+2$. S.E

Source: Author's computation using Eviews 9 software

\section{Conclusion and Suggestion}

This paper investigates wage-black economy relationship in Nigeria for the period 1990-2018. Phillips and Ouliaris (1990) single-equation residual-based cointegration tests did not confirm the existence of co-integration relationship among the variables, therefore, vector autoregressive (VAR) estimation technique was applied in assessing the dynamic relationship among the variables. Nonetheless, impulse response function was used to highlights the plausible responses from black economy to a shock of one standard deviation in each indicated variable. The result shows that a shock to national minimum wage (LOGMWA) will have a negative effect on black economy (LOGBEC) in Nigeria. Shocks to inflation (LOGINFL) will have a positive impact on black economy (LOGBEC). Shocks to tax (LOGATAX) will have asymmetric impacts on black economy (LOGBEC). The results were robust even when unemployment (LOGUEMP) was included. An unemployment shock was shown to enhance black economy in Nigeria.

In conclusion, national minimum wage is one among many policies that seek to improve lowskilled workers' incomes and keeping them away from black economy. However, caution should be taken so that it does not bring about unintended consequences like higher inflation, more unemployment, high taxation which could increase the size of black economy. As such, policy measures should be directed towards those causes that drive the black economy in Nigeria by making: 
- Policies directed towards easing of the burden and costs of taxes and regulations. This can be done by enabling the business sector through tax reduction and tax holidays to reduce operating costs.

- -Government should establish more industries and adopt policy of decentralization of the industrial sector to increase employment generation.

- Government should adopt adequate indirect instruments for the purpose of controlling the volume of money in circulation for effective and efficient control of inflation rate in Nigeria. In that regard, interest rate should be totally liberalized for the purpose of making it a strong monetary policy instrument of regulating price level and economic activities.

\section{Conflict of interests}

The author declares no conflict of interest.

\section{Funding}

The study has no financial assistance/funds to recognize.

\section{References}

Ariyo, A., and Bekoe.W. (2012). Currency Demand, the Underground Economy and Tax Evasion: Case of Nigeria, Journal of Monetary and Economic Integration, 2(2),130-157.

Burnett, K. (2018). Raising the Md. minimum Wage would Stabilize Families - and Destabilize the Underground Economy. https://www.baltimoresun.com/opinion/oped/bs-ed-op-0201-minimum-wage-20180131-story.html

Boeri, T., and Garibaldi, P. (2002). Shadow Activity and Unemployment in a Depressed Labour Market.

Clotfelter, C., (1983). "Tax Evasion and Tax Rates: An Analysis of Individual Returns," Review of Economics and Statistics, 65(3), 363-373.

CSEAAfrica(2019). Nigeria's New National Minimum Wage: Responses and Implications for the Economy.http://cseaafrica.org/nigerias-new-national-minimum-wage-responses-andimplications-for-the-economy/

Davidescu, A., Strat, V. A., \& Paul, A. M. (2015). Revisiting the Size of Romanian Informal Economy Using the Gutmann Approach, Procedia Economics and Finance, 23(1), 1037 1045.

Dell'Anno, R., and Solomon, O. H. (2008). Shadow Economy and Unemployment Rate in USA: is there a Structural Relationship? An Empirical Analysis, Applied Economics, 40(19), 2537- 2555.

Dobre, I., Alexandru, A. A., and Lepas, O. (2010). The USA Shadow Economy and the Unemployment Rate: Granger Causality Result,. Journal of Applied Quantitative Methods, 5(1), 98-104. 
DW (2015). Minimum Wage Fuels Germany's Underground Economyhttps://www.dw.com/en/minimum-wage-fuels-germanys-undergroundeconomy/a-18231218

Elijah, O. A., and Uffort, L.(2007). Comparative Analysis of the Relationship between Poverty and Underground Economy in the High Developed, Transition and Developing Countries, MPRA, Paper 2054.

Friedman, E., Johnson, S., Kaufmann, D., and Zoido-Labton, P. (2000). Dodging the Grabbing Hand: The Determinants of Unofficial Activity in 69 Countries, Journal of Public Economics, 76(3), 459-493.

Hall, A. (2019).Underground Economy.https://www.britannica.com/topic/underground-economy Herr, H., and Kazandziska, M. (2011), "Principles of Minimum Wage Policy - Economics, Institutions and Recommendations", International Labour Office, CH-1211 Geneva 22, Switzerland.

Ihendinihu, J.U. (2013). Analysis of t he Size of Unofficial Economy in Nigeria: Implications for Tax Revenue Generation and Sustainable Economic Growth, Journal of Business and Public Dynamics for Development, 1(1),15-31.

Ihendinihu, J.U., and Ochonma, G.C. (2010). Non Tax Factors as Critical Determinants of the Size of Underground Economy in Nigeria: Imperative for Policy Action, Journal of Emerging Trends in Economics and Management Sciences (JETEMS), 1(1), 13 - 22.

Johnson, S., Kaufmann, D., and Zoido-Lobaton, P. (1998). Regulatory Discretion and the Unofficial Economy, American Economic Review, 88(2), 387-392.

Jonah, N. (2009). Is this the Meaning of Deregulation? https://www.dailytrust.com.ng/is-thisthe-meaning-of-deregulation.html

Mankiw, N. G. (2011), Principles of Economics, Sixth Edition, USA: South-Western Cengage Learning

Mauleón, I., and Sardà, J. (2017). Unemployment and the Shadow Economy, Applied Economics, 49(37), 3729-3740.

McConnell, C. R., Brue, S. L., and Flynn, S. M. (2009), Economics: Principles, Problems, and Policies Boston: McGraw- Hill, Irwin.

Nmesirionye , J. A., and Ihendinihu, J. U. (2016).Underground Economic Activities and Tax Revenue Losses: Empirical Evidence from the Nigerian Economy, Journal of Emerging Trends in Economics and Management Sciences (JETEMS) 7(1), 67-74.

Okechukwu, A. (2017).Nigeria's Shadow Economy to Shrink to 46.11 Percent of GDP by 2025 - Study. https://allafrica.com/stories/201707040233.html

Ogbuabor, J, E., and Malaolu, V. A. (2013). Size and Causes of the Informal Sector of the Nigerian Economy: Evidence from Error Correction MIMIC Model, Journal of Economics and Sustainable Development 4(1), 30-41.

Oyedele, T. (2019). Should Government Increase VAT Rate to Pay for the New Minimum Wage?https://pwcnigeria.typepad.com/tax_matters_nigeria/2019/03/should-governmentincrease-vat-rate-to-pay-the-new-minimumwage.html?utm_source=Mondaq\&utm_medium $=$ syndication \&utm_campaign=ViewOriginal 
Saharareporters (2019). NIgerian Trade Union Tells Government to Pay Arrears Using New Minimum Wage Scheme. http://saharareporters.com/2019/10/22/nigerian-trade-uniontells-government-pay-arrears-using-new-minimum-wage-scheme

Schneider, F. (1986). Estimating the Size of the Danish Shadow Economy Using the Currency Demand Approach: An Attempt, Scandinavian Journal of Economics, 88(4), 643-668.

Slemrod, J. (1985). An Empirical Test for Tax Evasion, Review of Economics and Statistics, 67(2), 232-238.

Torgler, B. and Schneider, B. (2007). "Shadow Economy, Tax Morale, Governance and Institutional Quality: A Panel Analysis," Law and Economics Workshop, University of California, Berkeley, Paper 1.

Wage Indicator (2019).Minimum Wage - Nigeria. https://wageindicator.org/salary/minimumwage/nigeria 